\title{
Effects of Family Planning and Baby Care Behavior on Stunting in Early Married Couples
}

\author{
Rosmala Nur $^{1 *}$, Muhammad Rusydi ${ }^{1}$, Rasyka Nuru Fajriah ${ }^{1}$, Rahma Dwi Larasati ${ }^{1}$, St. Ika Fitrasyah ${ }^{2}$, Syaiful Hendra $^{3}$, \\ Hajra Rasmita Ngemba $^{3}$ \\ ${ }^{1}$ Department of Geophysics Engineeringm, Faculty of Mathematics and Natural Sciences, Tadulako University, Palu, Indonesia; \\ ${ }^{2}$ Department of Nutrition, Faculty of Public Health, Universitas Tadulako, Palu, Indonesia; ${ }^{3}$ Department of Information \\ Technology, Faculty of Engineering, Tadulako University, Palu, Indonesia
}

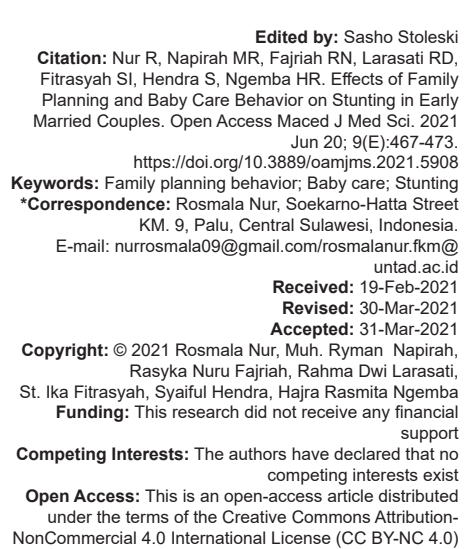

Introduction

In Indonesia, the data from Basic Health Research showed that the value of stunting in 2019 was $30.8 \%$ but later decreased to $27.67 \%$ [1]. Despite the decrease, this has become one of the national health problems because it is still above the $20 \%$ threshold [2]. In Asia, Indonesia ranks third with the highest stunting prevalence rate and in Central Sulawesi Province, it is still quite high, reaching $32.3 \%$ [3]. Stunting is characterized by growth and developmental failure, cognitive impairments and deficits, slow absorption of knowledge, weakness in mathematics and disorders of the body's metabolism, and exposure to noncommunicable disease. It has an impact on reducing intelligence and being vulnerable to illness, decreasing the economic productivity, exacerbating inequality, and poverty between generations, therefore preventing development and opportunities on the quest of becoming a first-class country [3].

Fertility rate (number of children) and family's birth distance are factors which influence stunting events. In Indonesia, birth rate is high reaching 2.4, while in Central Sulawesi, the total fertility rate is 2.7 and is in the $29^{\text {th }}$ position of all provinces in the country [2]. This is due to the considerable number of children suffering from malnutrition and stunting [4]. Furthermore, the involvement of mothers in earning a living in helping the family economy leads to an increase in nutritional value of under-five children [5]. Moreover, the birth distance of a child which is too close will affect the nutritional status in the family due to difficulty in care and lack of creating a calm atmosphere at home [6].

The fertility rate is closely related to the first procreating age. The lower it is, the higher the birth rate is expected. This is because young couples tend to have a large number of children [4]. Furthermore, early marriage affects the risk of pregnancy complications, bleeding, premature birth, and even has an impact on stunting, maternal, and infant mortality due to immature reproductive health of women [7].

In Central Sulawesi Province, the average age of first marriage is 19 years old. Results obtained from family data, broken down by district/city, showed that 
the province is one of the lowest and the average age of the first marriage is 19.96 years old.

Based on Table 1 Research on family planning behavior and baby care for early married couples in an effort to reduce the prevalence of stunting in the Marawola Public Health Center in Sigi District needs to be obtained. Although there have been many previous studies on this topic, its position is limited to mothers (wives) in fertile age, not only on married couples. Studies involving husbands and focusing on early marriage have not been conducted or utilized and it consequently leads to a decrease in stunting.

\section{Methods}

\section{Design, place, and study sample}

This research was an analytic survey conducted in the area of the Public Health Center in Marawola, Sigi District, Central Sulawesi. Purposive sampling technique was used with the following criteria: Married under age 21 years old (for his wife), the nuptial age id more than 3 years, having a Toddler, and mothers who have stunting children based on preliminary information from village midwives. This research was performed on November 2019 to February 2020.

\section{Data collection technique}

Research data were collected using direct interviews with the early married couples, focus group discussions, and observations.

\section{Data analysis techniques}

Used was Chi-square to analyze the relationship between family planning behavior and Baby Care (colostrum, immunization completeness, exclusive breastfeeding, PMT, breastfeeding for 2 years) with stunting disorders occurrence variables. Mouser's model of gender analysis was employed to identify the gender relations gap.

Table 1: Stunting prevalence and first marriage age in Central Sulawesi Province in 2018

\begin{tabular}{llll}
\hline S. No & District/City & Stunting & First marriage ages \\
\hline 1 & Banggai Kepulauan & 40.5 & 19.4 \\
2 & Banggai & 31.9 & 19.6 \\
3 & Banggai laut & 34.2 & 19.1 \\
4 & Morowali & 34.8 & 19.4 \\
5 & North Morowali & 28.5 & 19.0 \\
6 & Poso & 26.2 & 19.6 \\
7 & Donggala & 36.0 & 19.5 \\
8 & Tolitoli & 31.7 & 19.9 \\
9 & Buol & 34.2 & 19.8 \\
10 & Parimo & 33.7 & 19.0 \\
11 & Touna & 26.2 & 19.1 \\
12 & Sigi & 43.0 & 19.9 \\
13 & Palu & 24.1 & 21.0 \\
& Central Sulawesi & 32.3 & 19.0 \\
\hline Data source: Statistics Indonesia of Central Sulawesi Province in 2018.
\end{tabular}

\section{Results}

\section{Social characteristics of respondent demographics}

Characteristics of respondents can be seen by age, occupation, education, and number of children who are still alive.

Based on Table 2, this shows that they were still young and in terms of profession, on the average, they were a housewife by $67.5 \%$. This result shows that the respondents did not have a fixed income. Furthermore, judging from the level of education, most of them had high school education by $50.0 \%$. It means they have adequate education. However, the highest number of children was more than 3 children by $52.5 \%$. Therefore, the average respondents have children that are not ideal or not in accordance with the recommendations of the Government, which is having just two. In the distribution by age (husbands), the majority were 22-35 years old (47.5\%). These data show that the husband is relatively young and productive. Judging from their work, they are entrepreneurs by $50.0 \%$ and on the average level of education, only $35 \%$ graduated from Junior high School. Therefore, the average respondent's husband had a lower level of education than his wife.

Table 2: Respondents distribution by demographic social characteristics

\begin{tabular}{lll}
\hline Subject characteristics & Frequency & Percentage \\
\hline Wife & & \\
Profession & 7 & 17.5 \\
$\quad$ Employee & 6 & 15.0 \\
$\quad$ Entrepreneur & 27 & 67.5 \\
$\quad$ Housewife & 40 & 100 \\
Total & & \\
Education & 10 & 25.0 \\
$\quad$ Elementary School & 10 & 25.0 \\
$\quad$ Junior High School & 20 & 50.0 \\
$\quad$ Senior High School & 40 & 100 \\
Total & & \\
Number of children & 19 & 47.5 \\
$\quad \geq 2$ & 21 & 52.5 \\
3< & 40 & 100 \\
$\quad$ Total & & \\
Husband & & 20.0 \\
Age & 8 & 47.5 \\
$\quad<21$ years old & 19 & 32.5 \\
$\quad 21-35$ years old & 13 & 100 \\
35<years old & 40 & \\
Total & & 25.0 \\
Profession & 10 & 50.0 \\
$\quad$ Employee & 20 & 25.7 \\
Entrepreneur & 10 & \\
$\quad$ Civil servants & 40 & 35.0 \\
Total & & 35.0 \\
Education & 14 & 30.0 \\
$\quad$ Elementary School & 14 & 100 \\
Junior High School & 12 & \\
$\quad$ Senior High School & 40 & \\
Total & & \\
\hline$\quad$ & & \\
& &
\end{tabular}

\section{The relationship between family planning behavior and birth}

Table 3 shows that the status of contraceptive use has a relationship with birth of 0.001 or $p<\alpha 0.05$, concluding that there was a relationship between the status of family planning use and birth. 
Table 3: Respondents analysis based on contraceptives usage status with parity

\begin{tabular}{|c|c|c|c|c|c|c|c|}
\hline \multirow[t]{3}{*}{ Contraceptive usage status } & \multicolumn{4}{|c|}{ Parity } & \multicolumn{2}{|c|}{ Total } & \multirow[t]{3}{*}{$\mathrm{p}$ value } \\
\hline & \multicolumn{2}{|c|}{$\leq 2$ Children } & \multicolumn{2}{|c|}{$3<$ Children } & & & \\
\hline & $\mathrm{F}$ & $\%$ & $\mathrm{~F}$ & $\%$ & $\mathrm{n}$ & $\%$ & \\
\hline Use & 10 & 25.0 & 7 & 75,0 & 17 & 100 & 0.001 \\
\hline Do not use & 2 & 5.0 & 21 & 95.0 & 23 & 100 & \\
\hline Total & 12 & 30.0 & 28 & 70.0 & 40 & 100 & \\
\hline
\end{tabular}

\section{The relationship between birth and} stunting events

Table 4 shows the $p$ value for birth in relation to stunting which is 0.002 or $p<\alpha 0.05$. It can be concluded that there was a significant relationship between birth and stunting event.

Table 4: Respondents analysis based on parity with stunting status

\begin{tabular}{|c|c|c|c|c|c|c|c|}
\hline \multirow[t]{3}{*}{ Parity } & \multicolumn{4}{|c|}{ Stunting } & \multicolumn{2}{|c|}{ Total } & \multirow[t]{3}{*}{$p$ value } \\
\hline & \multicolumn{2}{|c|}{ Yes } & \multicolumn{2}{|l|}{ No } & & & \\
\hline & $\mathrm{F}$ & $\%$ & $\mathrm{~F}$ & $\%$ & $\mathrm{n}$ & $\%$ & \\
\hline$\leq 2$ Children & 4 & 26.6 & 11 & 73.4 & 15 & 100 & 0.002 \\
\hline$\geq 3$ Children & 8 & 32.0 & 17 & 68.0 & 25 & 100 & \\
\hline Total & 12 & 30.0 & 28 & 65.0 & 40 & 100 & \\
\hline
\end{tabular}

\section{The relationship between baby care and} stunting events

Table 5 showed the test results obtained $p$ value for cholesterol provision which was 0.0016 or $p<\alpha 0.05$, concluding that there was a significant relationship to the stunting event. Furthermore, exclusive breastfeeding and completeness of immunization with the $p=0.003$ showed that there was a significant relationship with stunting. In addition, supplementary feeding and breastfeeding for up to 2 years with a corresponding $p=0.002$ and 0.000 showed that there was a significant relationship with stunting events as well.

Table 5: Respondents analysis based on children care with the stunting status

\begin{tabular}{|c|c|c|c|c|c|c|c|}
\hline \multirow[t]{3}{*}{ Children care } & \multicolumn{4}{|c|}{ Stunting } & \multirow{2}{*}{\multicolumn{2}{|c|}{ Total }} & \multirow[t]{3}{*}{$p$ value } \\
\hline & \multicolumn{2}{|c|}{ Yes } & \multicolumn{2}{|l|}{ No } & & & \\
\hline & $\mathrm{F}$ & $\%$ & $\mathrm{~F}$ & $\%$ & $\mathrm{n}$ & $\%$ & \\
\hline \multicolumn{7}{|l|}{ Colostrum provision } & \multirow[t]{4}{*}{0.0016} \\
\hline Yes & 4 & 10 & 12 & 30 & 16 & 100 & \\
\hline No & 15 & 37.5 & 9 & 22.5 & 24 & 100 & \\
\hline Total & 19 & 47.5 & 21 & 52.5 & 40 & 100 & \\
\hline \multicolumn{8}{|c|}{ Exclusive breastfeeding } \\
\hline Yes & 6 & 15.0 & 20 & 50.0 & 26 & 100 & \multirow[t]{3}{*}{0.003} \\
\hline No & 11 & 7.5 & 3 & 7.5 & 14 & 100 & \\
\hline Total & 17 & 42.5 & 23 & 57.5 & 40 & 100 & \\
\hline \multicolumn{8}{|c|}{ Immunization completeness } \\
\hline Complete & 8 & 20.0 & 16 & 40.0 & 24 & 100 & \multirow[t]{3}{*}{0.003} \\
\hline Incomplete & 15 & 37.5 & 1 & 2.5 & 16 & 100 & \\
\hline Total & 23 & 57.5 & 17 & 42.5 & 40 & 100 & \\
\hline \multicolumn{8}{|c|}{ Supplementary feeding } \\
\hline Yes & 7 & 17.5 & 17 & 42.5 & 24 & 100 & \multirow[t]{3}{*}{0.002} \\
\hline No & 10 & 25.0 & 6 & 15.0 & 16 & 100 & \\
\hline Total & 17 & 42.5 & 23 & 57.5 & 40 & 100 & \\
\hline \multicolumn{8}{|c|}{ Breastfeeding up to 2 years old } \\
\hline Yes & 4 & 10.0 & 14 & 35.0 & 18 & 100 & \multirow[t]{3}{*}{0.000} \\
\hline No & 18 & 45.0 & 4 & 10.0 & 22 & 100 & \\
\hline Total & 22 & 55.0 & 18 & 45.0 & 40 & 100 & \\
\hline
\end{tabular}

Family planning behavior and baby care at early married couples in a gender perspective

The result using Moser techniques showed the planning stage (wife 98\%), making decision (wife
$80.0 \%$ ), and the implementation of family planning as well as baby care (wife $99.0 \%$ ). Therefore, it can be concluded that the idea was dominated by the wife.

\section{Discussion}

\section{The relationship between family planning} use and birth status

Results showed the relationship between the use of contraceptives and the number of children born by early married couples. This is because most women who are married use it for fertility reasons. They consider themselves at risk of pregnancy because of sex. These results are very accurate [8] and families having more than 2 children tend to adjust the use of contraceptives to limit births [9]. Furthermore, results [10] showed a relationship between contraceptive use and birth in Bangladesh. Increased access to various methods available at the nearest health facility is very important to increase its usage in married couples both in rural and urban areas in Haiti [10]. Recent findings [11] showed that there was a relationship between births and contraceptive prevalence in Zimbabwe. Therefore, all aspects need to be considered in the design strategies to effectively increase the use of modern contraception among newly married adolescents [11].

Women who have 1-2 children are more often found in contact with family planning staff in the past 6 months [12], [13], [14]. The use of modern contraception at the regional level is very good for overcoming birth problems in Ethiopia [15]. Therefore, it is clear that low fertility is caused by its usage.

\section{The relationship between birth and birth} spacing with stunting events

Statistical results showed a relationship between parity and stunting events. This is possible because the number of children in the family affects the availability of food and income levels. Families with low economic status have the opportunity of possibly suffering from malnutrition. This is in line with the previous research [16] that children from poor families are the most vulnerable. Increase in family members leads to decrease in food availability. Inadequate dietary intake is one of the direct causes of malnutrition because it can cause weight loss or stunting growth. Therefore, the number of recorded births is a factor that also determines the nutritional status [16]. Results also showed that the relationship between the number of children and nutritional status caused competition in facilities and infrastructure, food differences, and reduced care time, causing stunting. 
The birth distance of children which is too close will affect the nutritional status in the family due to difficulty in caring for them and creating a conducive home [6] and when too close, it affects the parenting to children, in which they tend to be inconvenienced, therefore it is less optimal in caring for the children [17].

Other findings in this study are the causal factor to the increasing number of children, including cultural factors; because boys are hereditary successors, most families keep wishing for them. It is very clear that decision-making on contraception is dominated by husbands. This is in line with research [18], [19], [20] stating that women do not have the power to determine the desired contraceptive methods because of their dependence on the husband's decision.

\section{The relationship between Baby care and stunting events}

\section{Colostrum}

The results showed that colostrum provision was related to the stunting events due to cholesterolcontaining substances and vitamins that are very good for children's development. This is in line with [21] that achieving optimal growth in the Global Strategy for Infant and Young Child Feeding, WHO recommends four important things, breast milk within 30 min after birth (giving colostrum), exclusive breastfeeding from birth until 6 months old, complementary food for babies 6 months-24 months made from cheap and easily obtained ingredients from the local area (indigenous food) [19], [21], and continuing the process until 24 months old or older.

Colostrum contains substances that are very good for young child. These results showed the findings [20], [21] that reduced colostrum intake contributes to stunting (AOR $=4.45)$ [22]. The odds were higher among children receiving small colostrum $(\mathrm{AOR}=2.806,95 \% \mathrm{Cl}=1.059-7.478)$. Colostrum $(A O R=2.806,95 \% \mathrm{Cl}=1.059-7.478)$.

\section{Exclusive breastfeeding}

There is a very significant relationship between exclusive breastfeeding and stunting events. Appropriate infant and young child feeding have been identified as one of the key determinants of children undernutrition [23], [24], [25]. These results showed the findings of 25 exclusive breastfeeding as a predictor of stunting in Meskan District, Southern Ethiopia.

Other results showed higher stunting rates among children who were not exclusively breastfed during the first 6 months (AOR 1.55, 95\% Cl: $1.07-$ 2.24) [26]. After birth, breastfeeding practices have an immediate effect on newborns; its non-exclusive absence and delayed initiation increase the risk of morbidity [27], [28], [29].

\section{Immunization completeness}

The completeness of immunization had a significant relationship with the stunting events. These results showed the findings of Kramer and Kakuma [30], Panda et al. [31], in which stunting was significantly associated with unvaccinated status $(p=0.003)$. Immunization in children is a protective measure to avoid various childhood diseases and stunting [32]. To reduce this burden in developing countries, major emphasis should be laid on improving the sociodemographic profile, promotion of breastfeeding, and vaccination practices [33], [34].

\section{Complementary foods for breast milk and} breastfeeding for up to 2 years old

According to statistical results, there was a relationship between complementary foods for breast milk and breastfeeding for up to 2 years with stunting status. Study [35] showed that when breastfeeding without complementary foods for breast milk is continued for more than 18 months, it leads to increased susceptibility to malnutrition and stunting. This duration without complementary foods has a significant relationship with the stunting event. This is due to delays in introducing supplements to the baby either due to ignorance of the mother or lack of resources in the household [17].

Other study results [7] showed that there was a negative relationship between breastfeeding and growth. It was found that low parental income affected low complementary foods for breast milk intake with high diarrhea morbidity. The provision of food and beverages in addition to breast milk in infants aged 0-6 months old causes the baby to experience digestive disorders - one of them being diarrhea - when the treatment is not good, it can lead to stunting in children. Therefore, it can occur in children of 2 years old or more but not accompanied by complementary foods for breast milk [34], [35]. The effect of breastfeeding did not show significant results when it is not accompanied by other factors [34], [35].

After the baby is 6 months old, both macro and micro nutritional needs cannot be fulfilled by breast milk. Furthermore, eating skills (promotor skills) continue to develop and babies begin to show an interest in other foods besides breastfeeding. Therefore, in Indonesia, based on the recommendations for Scaling up Nutrition, complementary foods for breast milk are given after the baby is 6 months old while it is continued at the request of the baby until the age of 2 years or older. Complementary foods for breast milk provision at the right time will be very beneficial for meeting the nutritional needs and growth and development of infants as well as the transition period to general food. The transition period is known as the weaning period. The timely delivery of complementary foods for 
breast milk is one of the factors that do not affect other stunting [34], [35].

\section{Family planning behavior and baby care in} early married couples in a gender perspective

The results of the Mozer analysis in this study showed that there are gaps in family planning and baby care behavior in early married couples. This is due to the community's assumption that it is a woman's responsibility because their nature is to get pregnant and give birth. The inability to make decisions (when to get pregnant, where to give birth, and who takes care of children), cultural attitudes, and family behaviors which tend to prioritize men cause unbalanced relations. This condition is in line with [36] on gender issues in the health of mothers and infants, in which the stunting prevalence as well as mortality rates is still high in Indonesia. Furthermore, unmet family planning needs occurred in women with the lowest level of welfare, lack of education, and living in rural areas. This will have high risks such as an increase in unwanted pregnancies and the risk of stunting in children.

The implementation of the Family Planning Program causes several gender issues that are very striking. First, men access to family planning information is still very limited, in which knowledge of family planning methods for women is greater than the male birth control, especially vasectomy. Second, the participation for vasectomy male birth control is only 0.2 percent [37]. The limited types of male contraception (only condoms and vasectomy) make men reluctant to become family planning participants. Third, there are still very few men who know the benefits of planning. Fourth, the husband is still dominant in decisions and reproductive health as well as planning the number and distance of childbirths [37]. The Family Planning program is one of the right steps to support the promotion of gender equality in reproductive health.

The gender gap between husband and wife causes a lack of information and attention about proper pregnancy and child care as well as lack of the right to health and safety themselves, resulting in the delay in knowing the existence of abnormalities in children. Likewise, the husband's ignorance in caring for children (immunization coverage, exclusive breastfeeding, supplementary feeding, and breastfeeding for up to 2 years) [38], [39] can cause stunting. Therefore, it is clear that this support can have important consequences for the stunting events.

\section{Conclusion}

Family planning behavior of early married couples influences high birth rate. Many of them affect the prevalence of stunting. Baby care (colostrum, exclusive breastfeeding, completeness of immunization, supplementary feeding, and breast milk for up to 2 years) affects the stunting events in early married couples. The use of family planning and child care is still dominated by wives. The gap in family planning and baby care behaviors occurs due to unequal power relations.

\section{Authors' Contributions}

Rosmala Nur (conceptualizing and designing the study, preparing the draft, revising as well as providing critique); Muh. Ryman Napirah (sectional scientific management); Rasyka Nuru Fajriah ${ }^{1}$ (analyzing and interpreting the data); Rahma Dwi Larasati (analyzing and interpreting the data); St. Ika Fitrasyah (analyzing and interpreting the data).

\section{Significance statement}

This study showed the relationship of family planning and baby care behaviors (colostrum, exclusive breastfeeding, immunization, supplementary feeding, and breastfeeding for up to 2 years) of stunting events on early married couples. This idea, ranging from decision making, planning, and implementation, is dominated by the wives.

\section{References}

1. Health Research and Development Agency, Ministry of Health Republic of Indonesia. 2013 Basic Health Research. Jakarta, Indonesia: Ministry of Health Republic of Indonesia; 2018. https://doi.org/10.25133/jpssv27n1.003

2. Central Sulawesi Provincial Health Office. Central Sulawes Province Health Profile in Palu, Indonesia: Central Sulawesi Provincial Health Office; 2019. p. 1-222. https://doi.org/10.15520/ jcmro.v2i05.165

3. The Indonesian Ministry of Health, Short Stunting Situations in Indonesia. Health Data and Information. Jakarta, Indonesia: The Indonesian Ministry of Health; 2018. https://doi. org/10.17501/24246735.2018.4105

4. Rana MJ, Goli S. Does planning of births affect childhood undernutrition ? Evidence from demographic and health surveys of selected South Asian countries. Nutrition. 2018;47:90-6. https://doi.org/10.1016/j.nut.2017.10.006 PMid:29429542

5. Fikru M, Van Doorslaer E. Explaining the fall of socioeconomic inequality in childhood stunting in Indonesia. SSM Popul Health. 2019;9:100469. https://doi.org/10.1016/j.ssmph.2019.100469 PMid:31485478

6. FentaHM, Workie DL, Zike DT, Taye BW, Swain PK. Determinants of Stunting among under-five years children in Ethiopia from 
the 2016 Ethiopia demographic and health survey: Application of ordinal logistic regression model using complex sampling designs. Clin Epidemiol Glob Health 2019;8:404-13. https://doi. org/10.1016/j.cegh.2019.09.011

7. Grantham-Mcgregor SM, Walker SP, Himes JH, Powell CA. The effect of nutritional children: The Jamaican supplementation study and stunting on morbidity in young. Trans R Soc Trop Med Hyg. 1993;87(1):109-13. https://doi. org/10.1016/0035-9203(93)90448-y

8. Brown W, Ahmed S, Roche N, Sonneveldt E, Darmstadt GL, Foundation MG. Impact of family planning programs in reducing high-risk births due to younger and older maternal age, short birth intervals, and high parity. Semin Perinatol. 2015;39(5):33844. https://doi.org/10.1053/j.semperi.2015.06.006 PMid:26169538

9. Fischer $\mathrm{S}$, Royer $\mathrm{H}$, White $\mathrm{C}$. The impacts of reduced access to abortion and family planning services on abortions, births, and contraceptive purchases. J Public Econ. 2018;167:43-68. https://doi.org/10.1016/j.jpubeco.2018.08.009

10. Lindrooth RC, Mccullough JS. On unplanned births. The Effect of Medicaid Family Planning Expansions on Unplanned Births. 2007;17:66-74.

11. de Vargas Nunes Coll C, Ewerling F, Hellwig F, Jardim A, De Barros D. Contraception in adolescence: The influence of parity and marital status on contraceptive use in 73 low-and middle income countries. BMC. 2019;16:21. https://doi.org/10.1186/ s12978-019-0686-9

12. Cyril A, Siaity E, BrownieS, Holroyd E. My husband will love me more if I give birth to more children: Rural women's perceptions and beliefs on family planning services utilization in a low resource setting. Int J Afr Nurs Sci. 2019;10:152-8. https://doi. org/10.1016/j.ijans.2019.04.005

13. Nur R, Saputri H, Rahman A, Hartini DA, Aiman U. Factors related to contraceptive selection of iud on mothers who are family planning acceptors in pantoloan community health center areas palu city. Int J Med Sci Clin Invent. 2019;6(2):4322-6

14. Rosmala N, Rahman A, Febriani D, Krisnasari S, Daniel V. Factors associated with the use of non-hormonal contraceptive methods in the pantoloan public health center Palu city. J Curr Med Res Opin. 2019;2(3):5-10. https://doi.org/10.15520/jcmro. v2i03.134

15. Godha D, Gage AJ, Hotchkiss DR, Cappa C. Predicting materna health care use by age at marriage in multiple countries. $J$ Adolesc Health. 2016;58(5):504-11. https://doi.org/10.1016/j. jadohealth.2016.01.001

16. Fatima S, Manzoor I, Joya AM, Arif S, Qayyum S. Stunting and associated factors in children of less than five years: $A$ hospital-based study. Pak J Med Sci2020;36(3):581-5. https:// doi.org/10.12669/pjms.36.3.1370

PMid:32292476

17. Akram R, Sultana M, Ali N, Sheikh N, Sarker AR. Prevalence and determinants of stunting among preschool children and its urban rural disparities in Bangladesh. Food Nutr Bull 2018;39(4):521-35. https://doi.org/10.1177/0379572118794770 PMid:30157677

18. Sapkota S, Kobayashi T, Takase M. Husbands' experiences of supporting their wives during childbirth in Nepal. Midwifery. 2012;28(1):45-51. https://doi.org/10.1016/j.midw.2010.10.010 PMid:21129829

19. Krueger LA, Reinhardt TA, Beitz DC, Stuart RL, Stabel JR Effects of fractionated colostrum replacer and Vitamins A, D, and $E$ on haptoglobin and clinical health in neonatal Holstein calves challenged with Mycobacterium avium ssp. paratuberculosis. J Dairy Sci. 2016;99(4):2884-95. https://doi.org/10.3168/ jds.2015-10395

PMid:26805975
20. Kahssay M, Woldu E, Gebre A, Reddy S. Determinants of stunting among children aged 6 to 59 months in pastoral community, Afar region, North East Ethiopia: Unmatched case control study. BMC Nutr. 2020;6(9):1-8. https://doi.org/10.1186/ s40795-020-00332-z

PMid:32153979

21. Hare K, Pletts S, Inabu $Y$, Haines D, Sugino T, Guan LL. Feeding colostrum or a 1: 1 colostrum: Milk mixture for 3 days postnatal increases small intestinal development and minimally influences plasma glucagon-like peptide-2 and serum insulin-like growth factor-1 concentrations in Holstein bull calves. J Dairy Sci. 2020;10(5):4236-51. https://doi.org/10.3168/jds.2019-17219

22. Jeyakumar A, Nikam S, Nayak S. Prevalence and risk factors of undernutrition among children less than 2 years in urban slums of Pune, Maharashtra, India. Ecol Food Nutr. Ecol Food Nutr. 2019;58(5):456-69. https://doi.org/10.1080/03670244.2019.161 3985

PMid:31082268

23. Yotebieng M, Labbok M, Soeters HM, Chalachala JL, Lapika B, Vitta BS, et al. Ten steps to successful breastfeeding programme to promote early initiation and exclusive breastfeeding in DR Congo: A cluster-randomised controlled trial. Lancet Glob Health. 2015;3(9):e546-55. https://doi.org/10.1016/ s2214-109x(15)00012-1

PMid:26246225

24. Susiloretni KA, Hadi H, Blakstad MM, Smith ER, Shankar AH Does exclusive breastfeeding relate to the longer duration of breastfeeding? A prospective cohort study. Midwifery. 2019;69:163-71. https://doi.org/10.1016/j.midw.2018.11.008 PMid:30522038

25. Walsh SM, Cordes L, Mccreary L, Norr KF. Effects of early initiation of breastfeeding on exclusive breastfeeding practices of mothers in Rural Haiti. J Pediatr Health Care. 2019;33(5):5617. https://doi.org/10.1016/j.pedhc.2019.02.010 PMid:31153727

26. Bogale B, Gutema BT, Chisha Y. Prevalence of stunting and its associated factors among children of 659 months in Arba Minch health and demographic surveillance site (HDSS), Southern Ethiopia: A community-based cross-sectional study. J Environ Public Health. 2020;2020:9520973. https://doi. org/10.1155/2020/9520973

PMid:32280353

27. Cai J, Zang X, Wu Z, Liu J, Wang D. Translocation of transition metal oxide nanoparticles to breast milk and o ff spring: The necessity of bridging mother-off spring-integration toxicological assessments. Environ Int. 2019;133(Pt A):105153. https://doi. org/10.1016/j.envint.2019.105153 PMid:31520958

28. Bordelon C, Wood T, Stallworth K. Clinician's guide to supporting women with breast milk pumping. Nurs Womens Health 2019;23(5):440-9. https://doi.org/10.1016/j.nwh.2019.07.003 PMid:31445990

29. Black RE, Allen LH, Bhutta ZA, Caulfield LE, de Onis M, Ezzati $M$, et al. Maternal and child undernutrition: Global and regional exposures and heath consequences. Lancet. 2018;371(9608):243-60. https://doi.org/10.1016/ s0140-6736(07)61690-0 PMid: 18207566

30. Kramer MS, Kakuma R. Optimal duration of exclusive breastfeeding. Cochrane Database Syst Rev. 2012;2012(8):CD003517. https://doi.org/10.1002/14651858. cd003517 PMid:22895934

31. Panda BK, Kumar G, Mishra S. Understanding the fullimmunization gap in districts of India: A geospatial approach. 
Clin Epidemiol Glob Health. 2020;8(2):536-43. https://doi. org/10.1016/j.cegh.2019.11.010

32. Doherty T, ChopraM, Tomlinson M, OliphantN, Nsibande D, Mason J. Moving from vertical to integrated child health programmes: Experiences from a multi-country assessment of the Child Health Days approach in Africa. Trop Med Int Health. 2010;15(3):296305. https://doi.org/10.1111/j.1365-3156.2009.02454.x PMid:20070638

33. Shah SM, Selwyn BJ, Luby S, Merchant A, Bano R. Prevalence and correlates of stunting among children in Rural Pakistan. Pediatr Int. 2003;45(1):49-53. https://doi. org/10.1046/j.1442-200x.2003.01652.x PMid:12654069

34. Nandi A, Kumar S, Shet A, Bloom DE, Laxminarayan R. Childhood vaccinations and adult schooling attainment: Longterm evidence from India's universal immunization programme. Soc Sci Med. 2020;250:112885. https://doi.org/10.1016/j. socscimed.2020.112885
35. Kain J, Uauy R. Targeting strategies used by the chilean national supplementary feeding programme. Nutr Res. 2001;21:677-88. https://doi.org/10.1016/s0271-5317(01)00271-8

36. Barir B, Murti B, Pamungkasari EP. The associations between exclusive breastfeeding, complementary feeding, and the risk of stunting in children under five years of age:A path analysis evidence from Jombang East Java. J Matern Chid Heath. 2019;4(6):48698. https://doi.org/10.26911/thejmch.2019.04.06.09

37. Tessema M, Belachew T, Ersino G. Feeding patterns and stunting during early childhood in rural communities of Sidama, South Ethiopia. Pan Afr Med J. 2013;14:75.

PMid:23646211

38. Breines I. Male Roles, Masculinities and Violence. Thousand Oaks: SAGE; 2013.

39. Kulczycki A. The determinants of withdrawal use in Turkey: A husband's imposition or a woman's choice? 2004;59(5):101933. https://doi.org/10.1016/j.socscimed.2003.12.014 PMid:15186902 